\title{
Using Video Recording to Improve Students' Speaking Ability
}

\author{
AgungWicaksono \\ University of Nusantara PGRI Kediri
}

East Java, Indonesia

\begin{abstract}
Improving learners' ability in speaking is one of the major problems faced by educators now days. Learners' speaking ability in my class is low including their pronunciation, fluency and their accuracy. Furthermore, most of learners are shy and afraid of making mistakes so there is no effort to try to use the target language in and out of class. The video recordings were the solution of the problems above and the problems were formulated as follows: can and to what extent video recording improve the learners' speaking ability and how to teach speaking using video recording. This research was carried out with third grade learners of Nusantara PGRI Kediri University in East-Java Indonesia, to find out the effectiveness of video recording to improve learners' speaking ability. The numbers of third grade learners are $\mathbf{2 1}$ male and $\mathbf{7 3}$ are female and the female learners are usually shy and afraid of making mistakes. The data shows that the learners have positive attitude toward video recordings, especially the video recording help them to notice and identify their weaknesses in speaking without embarrassments.
\end{abstract}

Keywords: speaking ability, video recording

\section{INTRODUCTION}

Based on the preliminary research, most of learners of ESL want to learn more on speaking. Even though they come from different background, gender and motivation, they want to improve their speaking and they admit that they are not good in speaking. It is in line with [1](Givon 1997:92) says "Face-to-face communication is the most fundamental mode of human language". Speaking is a productive oral skill. It consists of producing systematic verbal utterance to convey meaning[2](Nunan2003 : 48). It means speaking is put all ideas into words and arrange them in good system so the message is conveyed. Producing systematic verbal utterance needs time and process for learners to be good at it. This is supported by [3](Chaney 1998:13)"Speaking is the process of building and sharing meaning through the use of verbal or non verbal symbol in a variety of context. In the process of building and sharing meaning orally, some learners have problems with accuracy, fluency and appropriateness. Furthermore the learners have big problem with self confidence, so they always shy to use the target language. How they can improve their speaking when they never use. One of the reasons that the learners are shy because when they use the target language and they make mistakes all their classmates laugh. So in third grade of Nusantara PGRI Kediri university, East-Java Indonesia , the researcher use the video recording to facilitate the learners' in improving their speaking. Video recording can be access as many times as necessary to accurately evaluate the speakers' strengths and weaknesses [4](Christianson, Hoskins, and watanabe, 2009). When the learners are watching their performance recording, they can focus on their mistakes so they can correct them. The most important of watching their video recording is that the learners can watch it in private place so when they make mistakes nobody laugh at them.

\section{STATEMENT OF THE PROBLEM}

Learning to speak of other languages is not easy; the learners must put lot efforts to do it. There are many reasons that speaking is difficult; the language itself and the learners. The students of Nusantara PGRI kediri University have problems in speaking which involves fluency, grammar, pronunciation, vocabulary which is different with the students' mother tongue and the learners are passive, afraid of making mistakes and shy to use the target language in any kinds of situation.[5]Richards (1992:141) stated that fluency as "the features which gives speech the qualities of being natural and normal." So it is very hard to make the learners can be natural and normal in speaking without lots of practice and reflection. Furthermore the grammar, vocabulary and pronunciation relates with accuracy also become big problem in speaking. This is in line with 
[6]Thornbury(2005), the terms accuracy seems to cover more than that. Specially in speaking accuracy means doing without or few errors on not only grammar, but also vocabulary and pronunciation.

The problems are formulated as follows:

1) Can and to what extent video recording improve students' speaking ability?

2) How is the process of teaching and learning speaking using video recording?

\section{METHOD}

This research is carried out as class action research in collaboration with two English lecturers in university of Nusantara PGRI Kediri. Some definitions of the action research that are proposed by experts are as follows: Burns (1993: 30) states that action research is the application of fact finding to practical problem solving in social situation with a view to improve the quality of action within it, involving the collaboration and cooperation of researcher, practitioners and laymen. [7]Bodgan and Biklen (in Burns, 1999: 30) define action research as the systematic collection of information that is designed to bring about social change. [8]McNiff (1998: 18) states

"Action research is different from other more traditional or conventional types of research in that it is very focused on individual or small-group professional practice and is not so concerned with making general statements. The main function of action research is to facilitate the 'reflective cycle', and in this way provide an effective method for improving professional action”.

Based on the above statements, it can be concluded that action research is a process of reflection and examine their social and educational practices systematically. The reflection used the technique of research in order to bring about social change and effecting positive improvement.The action research spiral based on [8]Kemmis and Mc Taggart

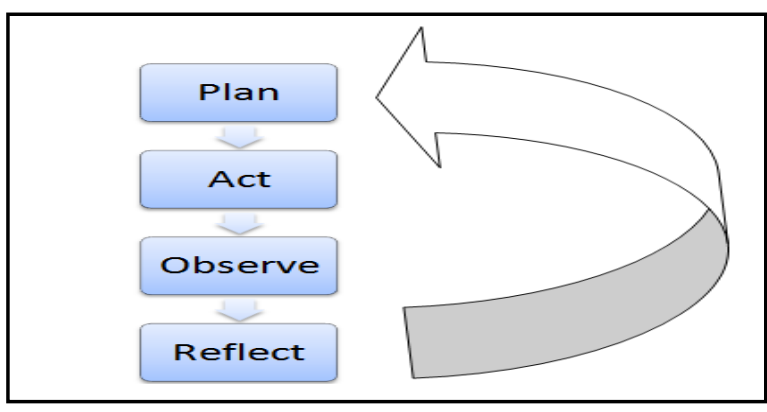

Fig 1.The Action Research Spiral

The researcher uses some steps as in kemmis and taggart which are Plan, Act, Observe and Reflect. The research is carried out in two cycles.

\section{Preliminary research \\ - Interviewing some students \\ II. Research Implementation \\ Cycle : Using video recording for improving the students' speaking
1. Planning
2. Acting
4. Reflecting \\ 3. Observing}

\section{Post-research}

- Questionnaire

Fig 2. Research Cycle

\section{RESEARCH RESULT AND DISCUSSION}

In preliminary research, the researcher interviewed some students, they said that speaking is difficult and they are shy to use the target language in class, because when they make mistakes in pronunciation or vocabulary used all their classmates are laughing at them. This is the main problem of all the students; they are so demotivated to practice and to use the target language.

\section{A. Planning}

In this stage the researcher worked together with a collaborator to make a lesson plan. We set the objectives of the teaching learning which is improving their speaking in doing presentation. The media for recording is 
prepared and checked to make sure it works and some students use their own recordings.

\section{B. Acting}

The researcher explained about the objectives of teaching and learning. There were 30 students in this class and most of them are girls. The students were learning speaking for presentation. Firsts, the researcher gave a role to each student, such as: as a doctor, headmaster and others for their presentation and ask them to make groups with the same role. There were 10 groups and 3 students who had the same role.Second, The researcher gave the handout of steps in presentation: 1. Greeting, 2. Name and position, 3. Title/Subject, 4. Objective, 5. Main parts/outlines, 6. Visuals, 7. Timing, 8. Question/answer, after that the researcher gave some examples of phrases or expressions in each step of presentation. The researcher asked themto discuss in group that has the same role to decide the topic of their presentation. During the discussion and teaching learning process most of the students and most of the time used Indonesian. I told them many times to use English but it didn't work. I noticed that when a student tried to speak English when he/she made mistakes most of the students in the class were laughing. After the lecturing have finished I asked the students to practice in the place where they can record it. I ask the students to watch their recording and write down the mistakes and correct them by themselves and the lecturer. We correct the mistakes on the steps of speaking for presentations and their pronunciation. This acting was last in three meetings

\section{Observing}

In teaching learning process the collaborator helped the lecturer to observe the students. During the observation the collaborator write some notes that many students used Indonesian in their discussion, most of students were shy when their classmates laughed at them when they make mistakes. In second and third meeting after they recorded their speaking practice and we corrected them they were more confident and used more English.

\section{Reflecting}

In this phase the writer and the collaborator discussed about the teaching learning process, in the first meeting most of students used Indonesian in their discussion and in interacting each other. The second and third meeting they were very happy and have positive attitude toward recording their speaking for presentation. The can rerecording after they got the feedback from the lecturer and corrected their own mistakes. This research is time consuming so it's better one of assessment is using peer assessment.

\section{CONCLUSION}

The interview shows that almost all of students have problem in speaking. They said that the pronunciation is difficult because the written word and the way how to spell is different. They don't have enough chance to practice their English. They don't feel comfortable to use English in class and this is the hottest issue that almost all students said that they are shy when they make mistakes, all their classmates are laughing at them. So with video recording they can practice and use English as many as they can, the students can repeat on the pronunciation which is difficult for them. They can make mistakes without having embarrassment means the students can make mistakes and nobody laugh at them so the students feel comfortable at practice their speaking. They can correct their own mistake at any time because they bring home the recording. We can conclude the use of video recording in improving speaking is very effective and useful especially toward students' attitude toward speaking. This is supported by the result of the questionnaire almost all students like using video recording in practicing speaking, all students watch their video more than twice means they do self-correction and they practice more.

\section{REFERENCES}

[1] Givon, T. 1997.Conversation: cognitive, communicative and social perspectives. Amsterdam: Benjamins.

[2] Nunan, D. (ed.). 2003.Practical English Language Teaching. New York: McGraw-Hill.

[3] Christianson, M., Hoskins, C., \& Watanabe, A. 2009. "Evaluating the effectiveness of a videorecording based self-assessment system for academic speaking. Language Research Bulletin, 
24, 1-15."Retrieved from

http://web.icu.ac.jp/lrb/docs/Christianson -HoskinsWatanabe.pdf

[4] Thornbury, S. 2005.How to Teach

Speaking. Harlow: Longman.

[5] Kemmis and Mc. Taggart. 1984. Class

Action Research.Deakin university press

[6] Benson, P. (2008).Teachers' and learners' perspectives on autonomy.In T. Lamb \& $\mathrm{H}$. Reinders (Eds.), Learner and teacher autonomy: Concepts, realities, and responses (pp. 15-32). Philadelphia, PA: John Benjamins.

[7] Best, J. W. (1981).Research in education (4thed.). Englewood Cliffs, NJ: Prentice Hall.

[8] Dam, L. (2000).Evaluating autonomous learning. In B. Sinclair, I. McGrath, \& T. Lamp (Eds.), Learner autonomy, teacher autonomy: Future directions (pp. 48-59). Harlow, England: Pearson.

[9] Dickinson, L. (1987).Self-instruction in language learning. Cambridge, England: Cambridge University Press.

[10] Holec, H. (1981).Autonomy and foreign language learning. Oxford, England: Pergamon.

[11] Nuchanart, D. (1992). The effects of selfassessment on the development of oral presentation skills.(Unpublished MA thesis).King Mongkut's University of Technology Thonburi, Bangkok, Thailand.

[12] Oscarson, M. (1989). Self-assessment of language proficiency: Rationale and applications. Language Testing, 6(1), 1-13. http://dx.doi.org/10.1177/0265532289006001 $\underline{03}$

[13] Oxford, R. L. (1990). Language learning strategies: What every teacher should know. New York, NY: Newbury House.

[14] Sinclair, B. (2000). Learner autonomy: The next phase? In B. Sinclair, I. McGrath, \& T. Lamb (Eds.), Learner autonomy, teacher autonomy: Future directions (pp. 4-14). Harlow, England: Pearson.

[15] Sintupan, S. (1990).Developing selfcorrection in speaking activity at secondary school level: An experiment in learner's linguistic independence.(Unpublished MA Thesis). King Mongkut's University of Technology Thonburi, Bangkok, Thailand. 